\title{
MODIFICATION OF REINFORCED CONCRETE RETAINING WALL AT PILANGBANGO RESERVOIR CONSTRUCTION PROJECT MADIUN, EAST JAVA
}

\author{
Mudji Irmawan ${ }^{1}$, Yerry Kahaditu Firmansyah. ${ }^{2}$, Afif Navir Refani ${ }^{3}$ \\ ${ }^{1}$ Program Studi Teknik Sipil FTSP ITS, Surabaya \\ ${ }^{2}$ Universitas Pembangunan Nasional " Veteran" Jawa Timur \\ ${ }^{3}$ Program Studi Diploma Teknik Sipil FTSP ITS, Surabaya \\ E-Mail :mudji.irmawan.arkani@gmail.com,yerry.kaha@gmail.com,navir.refani@gmail.com
}

\begin{abstract}
The reservoir is the tendon of water in order to accommodate the excess rain water in the rainy season and its utilization in the dry season for various purposes, both in the field of agriculture as well as the interests of the community. To find out the cause of the crack wall of the reservoir Pilangbango Madiun, East Java, then do the test strongly press on concrete walls and soil investigations on the area of the reservoir. Spunpile $400 \mathrm{~mm}$ in diameter used by the mounting distance $200 \mathrm{~cm}$ and a depth of $12 \mathrm{~m}$ and pole mounted on the heels of concrete walls. Manual calculation of the results and analysis of the Finite Element program it can be concluded that in the presence of an additional retaining her 400 spunpile mm using a distance $200 \mathrm{~cm}$ and a depth of $12 \mathrm{~m}$, retaining wall construction is then quite able to hold style pillow case and Sliding with style has a safety factor more than 1.5. So the movement of the sliding walls do not happen again.
\end{abstract}

Keywords : Reservoir wall stability, Reinforcement modification, Finite Element.

\section{INTRODUCTION}

Temporary water or shelter is often referred to with the bozem construction should be built as sturdy as possible so that it can function optimally. However, the construction of the bozem Pilangbango Madiun, East Java does not run as expected which is occurring cracks on the walls of the bozem. As for the picture of the construction of the Pilangbango dam before the modification of reinforcement purposes ( Figure 1) to anticipate more severe then the damage is done by modifying the structure of the dam retaining of course with a lot of reviewing aspects of the styles that occurred at the bozem construction.

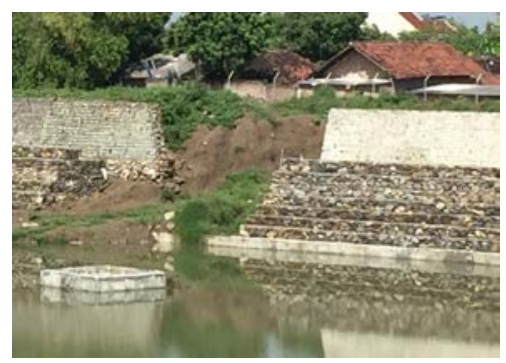

Figure 1. Existing conditions field (without reinforcement)

\section{METHODOLOGY}

In this research the data required are secondary data. Secondary data include data on the investigation of soil, the floor plan of the existing dam, construction Details, pieces of the Pictures and specifications of the materials used.
From the data already collected, analyzed what causes occurrence of shift and cracks on the walls of the bozem. The analysis was conducted would result in measures to resolve the problem by using a solutions based on by the theories and the study of literature.

As for systematic problem solving based on the theory that there is organized as follows:

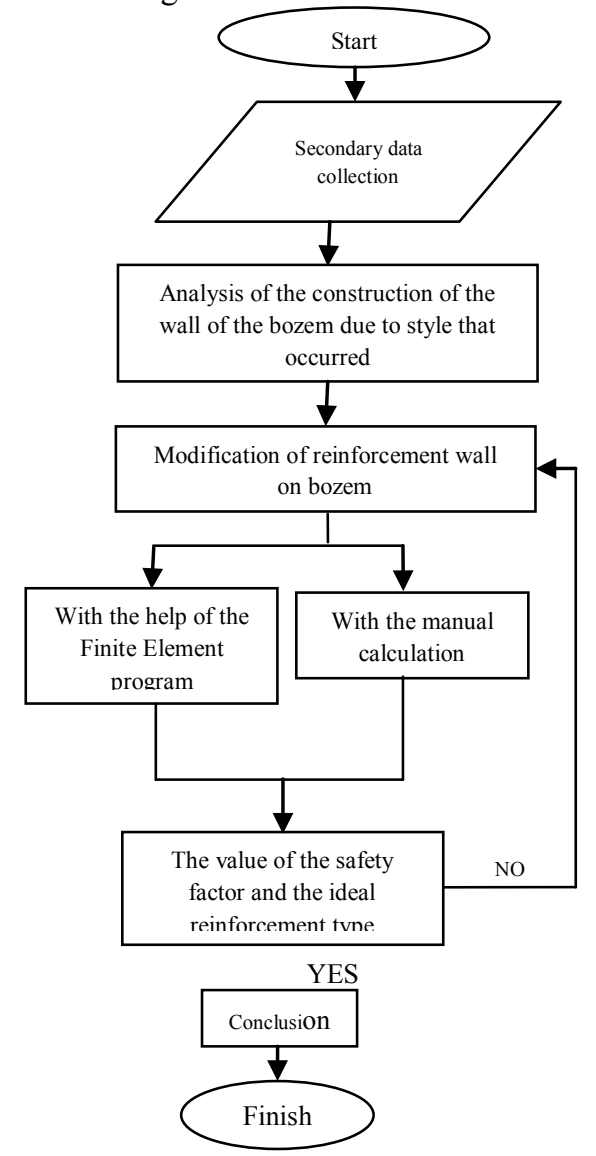




\section{RESULTS AND DISCUSSION}

Ground investigation data used in the analysis of retaining wall of the bozem is the borehole B-1 because it is considered to have a tendency of value N-SPT is relatively small. As for the Division of the soil layers in the Finite Element modelling will be done is as follows:

0.00

$$
\begin{array}{r}
\mathrm{N}-\mathrm{SPT}=9 ; \gamma_{\mathrm{sat}}=19,6 \mathrm{kN} / \mathrm{m}^{3} ; \mathrm{c}^{\prime} \\
=22,7 \mathrm{kPa} ; \phi=12^{\circ} \\
\text { Clay Silt }
\end{array}
$$

$$
8.00 \begin{array}{r}
\mathrm{N}-\mathrm{SPT}=12 ; \gamma_{\mathrm{sat}}=18,93 \mathrm{kN} / \mathrm{m}^{3} ; \mathrm{c}^{\prime}= \\
14,74 \mathrm{kPa} ; \phi=21^{\circ} \\
\text { Silty Sand }
\end{array}
$$

10.00

$$
\begin{array}{r}
\mathrm{N}-\mathrm{SPT}=20 ; \gamma_{\mathrm{sat}}=17,3 \mathrm{kN} / \mathrm{m}^{3} ; \mathrm{c} \\
=20,1 \mathrm{kPa} ; \phi=14^{\circ} \\
\text { Clay Silt }
\end{array}
$$

$$
\begin{array}{r}
\mathrm{N}-\mathrm{SPT}=10 ; \gamma_{\mathrm{sat}}=18,51 \mathrm{kN} / \mathrm{m}^{3} \\
=16,08 \mathrm{kPa} ; \phi=19^{\circ} \\
\text { Silty Sand }
\end{array}
$$

16.00

$$
\begin{array}{r}
\mathrm{N}-\mathrm{SPT}=20 ; \gamma_{\mathrm{sat}}=16,16 \mathrm{kN} / \mathrm{m}^{3} ; \mathrm{c}^{\prime}= \\
24,12 \mathrm{kPa} ; \phi=10^{\circ} \\
\text { Clay Silt }
\end{array}
$$

20.00

$$
\begin{array}{r}
\mathrm{N}-\mathrm{SPT}=50 ; \gamma_{\text {sat }}=16,86 \mathrm{kN} / \mathrm{m}^{3} ; \mathrm{c}^{\prime} \\
=18,09 \mathrm{kPa} ; \phi=17^{\circ} \\
\text { Silty Sand }
\end{array}
$$

24.00

Above ground as well as data from Picture 1. Existing conditions field (without any reinforcement purposes) then gained modeling for Finite Element as follows:

\footnotetext{
a) Analysis With The Finite Element Program (without any reinforcement purposes)
}

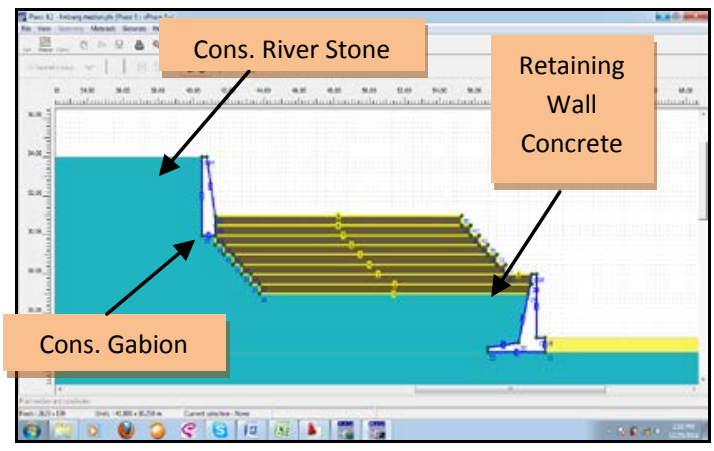

Figure 2. Initial Sketch Modeling

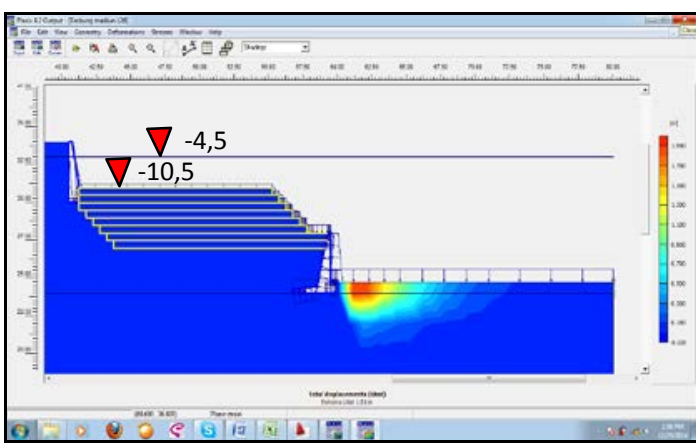

Figure 3. Distribution Voltage that occurs (without retaining)

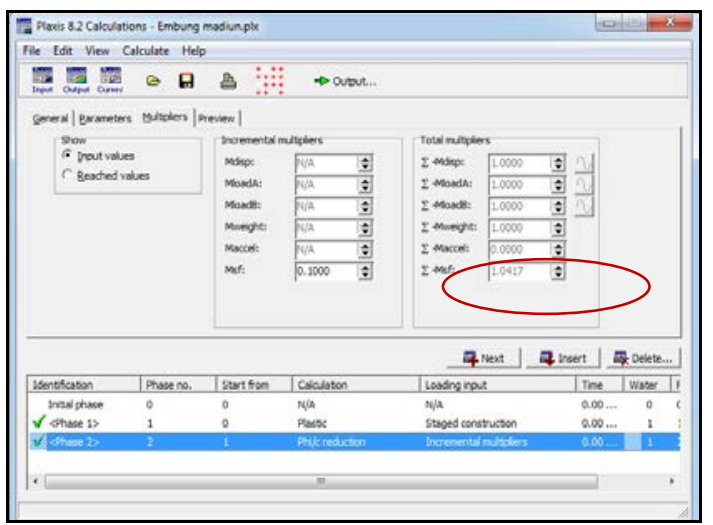

Figure 4. Calculations Result The obtained Values SF 1.04

From the results of the analysis above, that the structure of the dam without retaining additional security number value obtained amounted to 1.04. To increase the number of security then used an additional retaining the form of spunpile and pair of stone times. As for retaining models that will be done is as follows: 


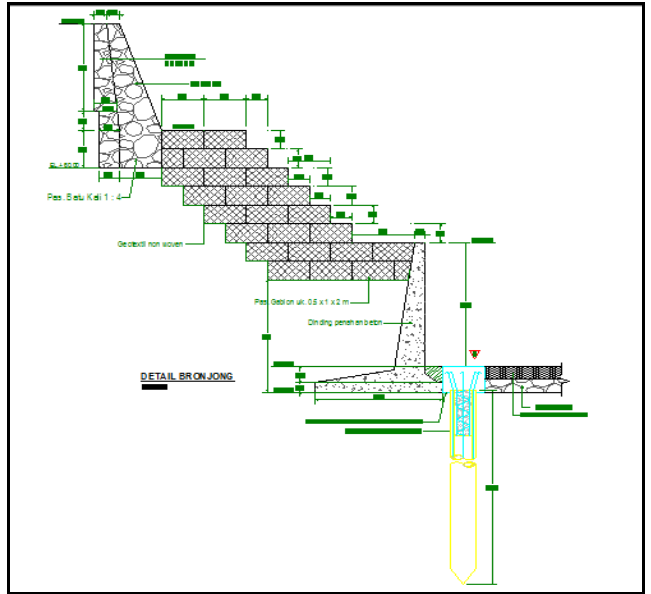

Figure 5. Existing conditions field (with a retaining)

Types of data and retaining wall of the dam will be used:

- Spunpile 400 with a length of 12 meters as well as the distance center to center is 2 meters.

- Stone Couple times approx 0.30 metres mounted on the base of the dam as a counter weight.

b) Analysis With The Finite Element Program (with a reinforcement)

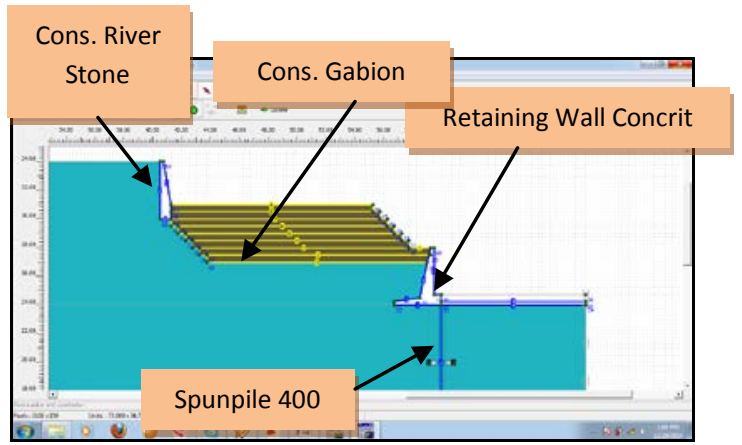

Figure 6. Initial Sketch Modeling

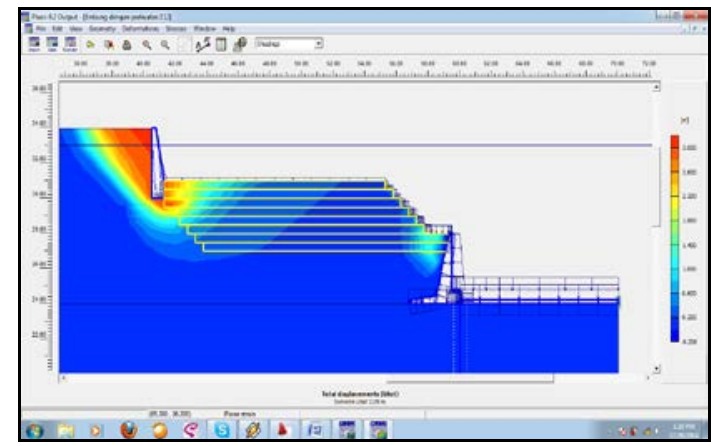

Figure 7. Distribution Voltage that occurs (with a retaining)

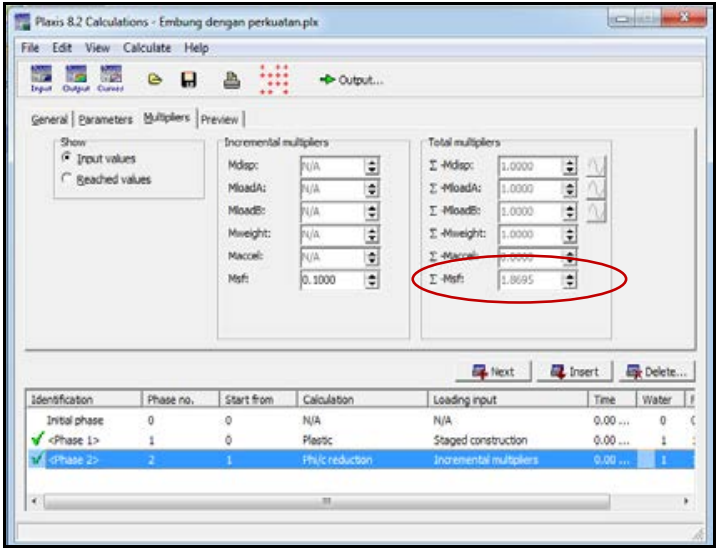

Figure 8. The results of the Calculations Obtained the value SF 1.86

c) Control Styles That Occurred In The Structure Of The Reservoir

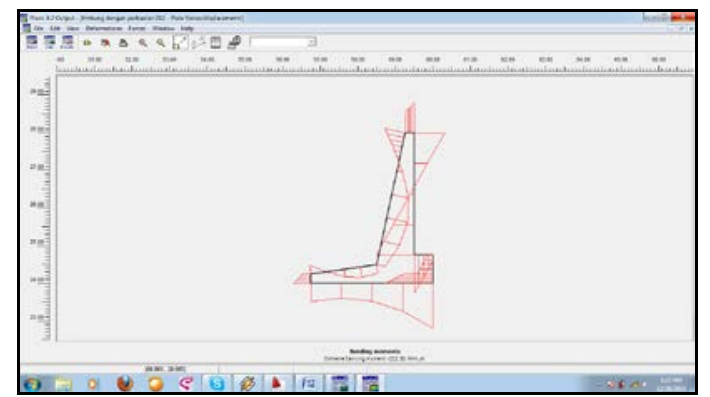

Figure 9. Bending Moment happens on the Concrete retaining walls of $232.50 \mathrm{kN} . \mathrm{M}$

If the magnitude of the bending moment that occurs in concrete retaining walls of $232.50 \mathrm{kN}$. $\mathrm{m}$, then the magnitude of the style press, $\mathrm{P}$ happens bending moment occur High wall 232.50 7.04 3.3 tons.

When the quality of concrete used was K-225 capacity then permit materials concrete retaining walls, concrete Quality material permits $\mathrm{P}_{\text {alloweble material }}=$ Concrete qulity $\mathrm{x}$ height wall $\mathrm{x}$ width wall (as wide as center to center on a pile) $=2250 \times 3.3 \times 214850$ ton. $\mathbf{P}$ happened $<\mathbf{P}$ material permit capacity.... (Secure)

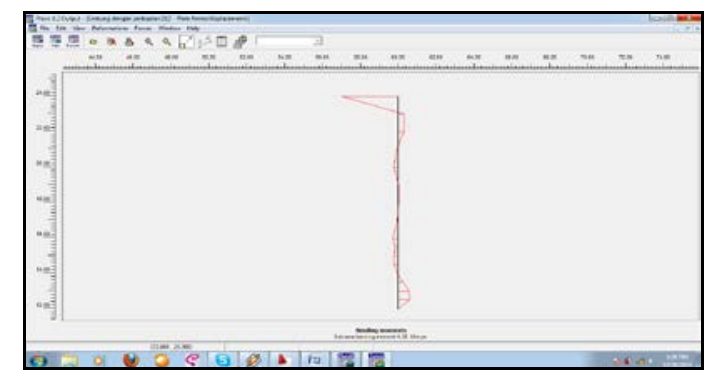

Figure 10. Bending Moment happens on the Spun pile Of $4.15400 \mathrm{kN} . \mathrm{m}$ 


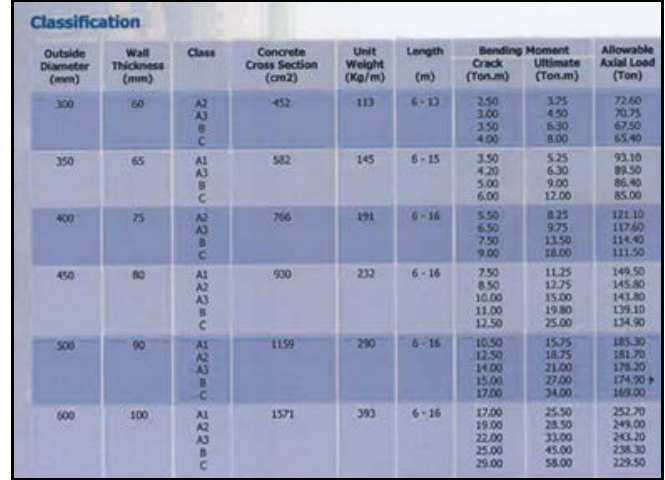

Figure 11. Classification Of The Spun Pile Brochure

To the capacity of the Spun Pile, the magnitude of the bending moment that happened was $0.41 \mathrm{~m}$ ton. While capacity materials based on brochure above is $9 \mathrm{~m}$ ton.

$\mathbf{M}_{\text {happened }}<\mathbf{M}_{\text {material permit .... ( Secure ) }}$

d) Power Control Support Under The Concrete Reinforcement Walls

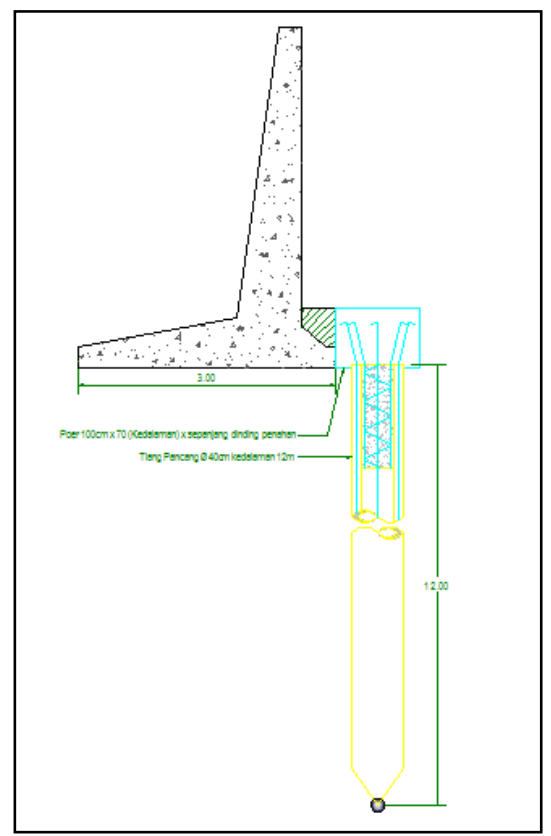

Figure 12. Construction Of A Concrete Wall.

$\mathrm{Q}_{\text {ult }}=1 / 2 \times \gamma^{\prime} \times \mathrm{B} \times \mathrm{N} \gamma+\mathrm{C}^{\prime} \times \mathrm{Nc}+\mathrm{q} \times \mathrm{Nq}$

The Foundation Continuously $=1 / 2 \times 0,96 \times 3 \times 0,86+2,2$

$$
\text { x } 9,4+0 \times 5,44
$$$$
=21,92 \mathrm{t} / \mathrm{m}^{2}
$$

If the Foundation width as wide as the center review to center on 2 meters, then:

$\mathrm{Q}_{\text {ult }}=21,92 \mathrm{t} / \mathrm{m}^{2} \times 2$ meter $\times 3,3$ meter

$$
=144,67 \text { ton }
$$

$\mathrm{Q}_{\text {all }}=\mathrm{Q}_{\mathrm{ult}} / \mathrm{SF}$

$$
=48,2 \text { ton }
$$

where,

$\mathrm{B}=$ Wide base the foundation $(\mathrm{m})$

$$
\begin{aligned}
& \begin{aligned}
\gamma^{\prime} & =\text { Effective land heavy volume }\left(\mathrm{t} / \mathrm{m}^{3}\right) \\
& =\gamma_{\mathrm{sat}}-\gamma_{\mathrm{w}}
\end{aligned} \\
& \begin{aligned}
\mathrm{C} & =\text { Effective cohesion land }\left(\mathrm{t} / \mathrm{m}^{2}\right) \\
& =2 / 3 \times \mathrm{C}_{\mathrm{u}}
\end{aligned} \\
& \begin{aligned}
\mathrm{q} & =\text { Load as deep as } \mathrm{D} \text { from land face lowest }\left(\mathrm{t} / \mathrm{m}^{2}\right) \\
\mathrm{D} & =\text { High foundation }(\mathrm{m}) \\
\mathrm{N} & \gamma, \mathrm{Nc}, \mathrm{Nq}=\text { Reduction Factor }(\text { table })
\end{aligned}
\end{aligned}
$$

Table 1. Reduction Factor

\begin{tabular}{cccc}
\hline$\varnothing^{\circ}$ & $\mathrm{Nc}$ & $\mathrm{N} \gamma$ & $\mathrm{Nq}$ \\
\hline 0 & 5.14 & 0.00 & 1.00 \\
5 & 6.50 & 0.10 & 1.60 \\
10 & 8.40 & 0.50 & 2.50 \\
15 & 11.00 & 1.40 & 4.00 \\
20 & 14.80 & 3.50 & 6.40 \\
25 & 20.70 & 8.10 & 10.70 \\
30 & 30.00 & 18.10 & 18.40 \\
35 & 46.00 & 41.00 & 33.30 \\
40 & 75.30 & 100.00 & 64.20 \\
45 & 134.00 & 254.00 & 135.00 \\
\hline (Source: Terzaghi K, Peck R.B, 1967$)$
\end{tabular}

Calculation of power support permission powerboats spun type diameter of $40 \mathrm{~cm}$ with a depth of 12 meters is 41.5 tons, recapitulation of the calculation can be seen in table 2 below. 
Table 2. Power Pole Support $\varnothing 40 \mathrm{~cm}$

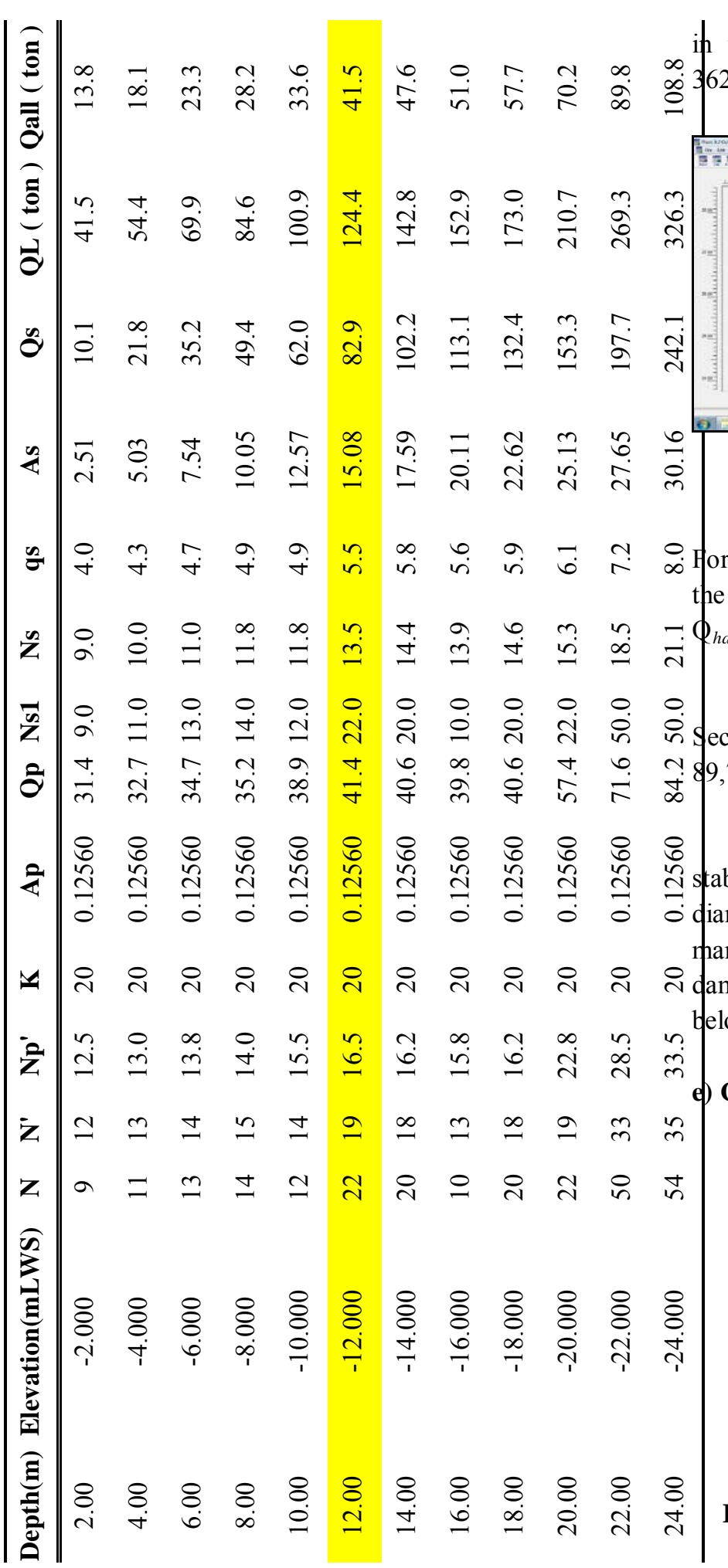

$$
=89,7 \text { ton }
$$
As for the magnitude of the axial style happens to be the concrete wall of a finite element modeling of if the concrete wall of a finite element modeling of
$362.60 \mathrm{kNm}$.

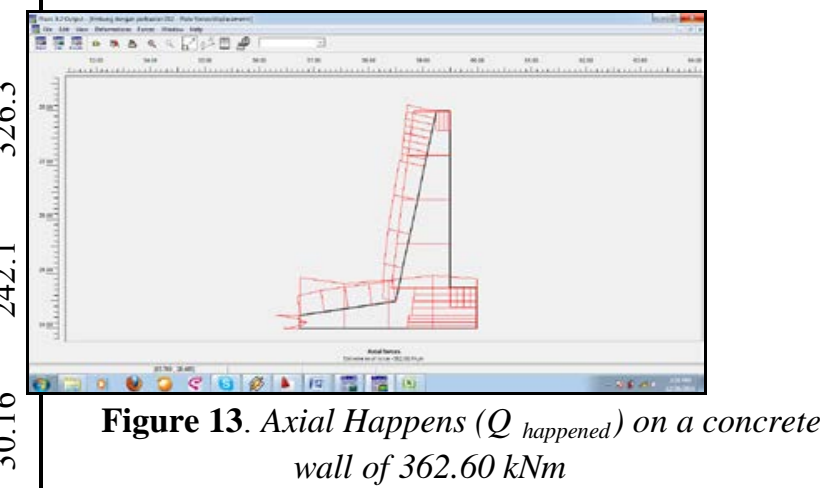

For the width of the Foundation, as wide as center into the center on 2 meters, then:

$\oint_{\text {happened }}=36,260 \mathrm{t} / \mathrm{m} \mathrm{x} 2 \mathrm{~m}$

$=72,4$ ton

Secure Requirements: $\mathrm{Q}_{\text {all ( DDT ) }} \geq \mathrm{Q}_{\text {happened }}$

$\$ 9,7$ ton $\geq 72,4$ ton.

SECURE

Based on the analysis of Finite Element against the stability of retaining wall with the do use spun pile diameter $40 \mathrm{~cm}$ ideal conditions obtained. As for the nanual calculation analysis against the stability of the wall construction the following analysis looks like below:

Control Against Overturning

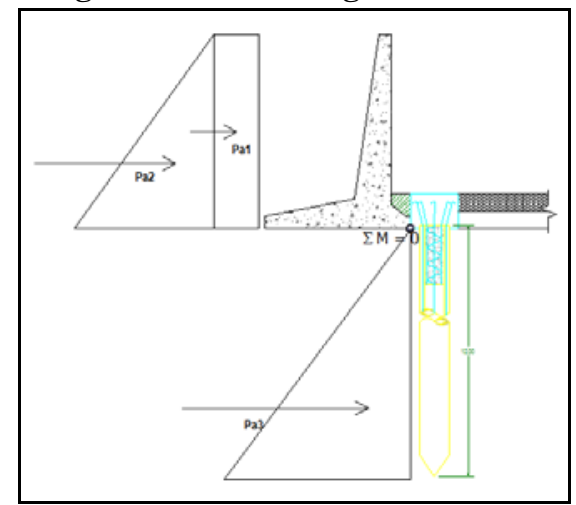

Figure 14. Sketch Styles For A Control Analysis Of Rolling

Point $\mathrm{A}$ is the point of the pillow case that is on a heel of concrete retaining walls $\mathrm{SF}=$ Momen Penahan $/$ Momen Guling

$=\mathrm{Mp} / \mathrm{Mg} \geq 2$

$\mathrm{Ka}=\tan ^{2}(45-\varphi / 2)$

$=\tan ^{2}(45-12 / 2)$ 


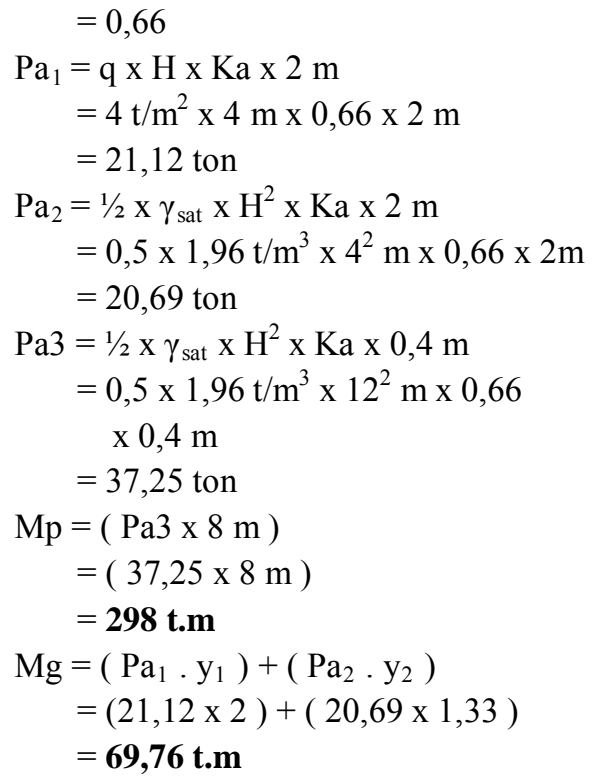

where,

$\mathrm{Ka}=$ Coefficient of active soil

$\mathrm{Pa}_{1}=$ Force pressure active due to load evenly ( ton )

$\mathrm{Pa}_{2}=$ Lateral force pressure land active ( ton )

$\mathrm{Pa} 3=$ Lateral force pressure land active ( ton )

$\varphi=$ Angles sliding the ground in $\left({ }^{\circ}\right)$

$\gamma_{\text {sat }}=$ Heavy volume wet land $\left(\mathrm{t} / \mathrm{m}^{3}\right)$

$\mathrm{H}=\operatorname{Depth}(\mathrm{m})$

$\mathrm{Mp}=$ Retaining moment $(\mathrm{t} . \mathrm{m})$

$\mathrm{Mg}=$ Rolling moment ( t.m )

Safe Condition: $\mathrm{Mp} / \mathrm{Mg} \geq 2$

298 t.m / 69,76 t.m $\geq 2$

$4,27 \geq 2$.............. Secure

\section{f) Control Of Sliding}

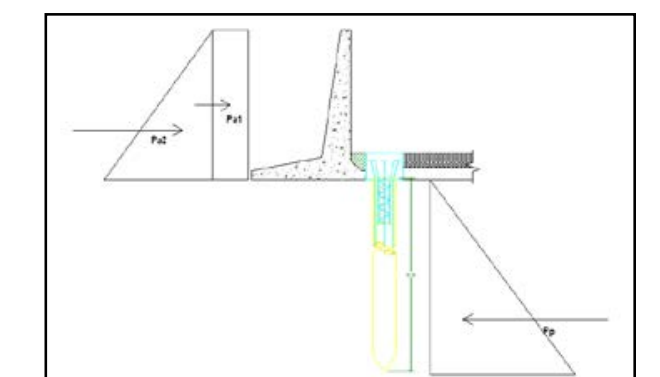

Figure

15.

Sketch

Styles For

A Control

Analysis

Of Shear
$\mathrm{SF}=$ Sliding force resistance

$=\mathrm{Fp} / \mathrm{Fg} \geq 1,5$

$=(\mathrm{Pp}) /(\mathrm{pa} 1+\mathrm{pa} 2)$

$=(85,8) /(21,12+20,69)$

$=2,05 \geq 1,5$

Secure

where,

$\mathrm{Kp}=$ Coefficient of passive soil

$\mathrm{Pa}_{1}=$ Style pressure active due to load evenly ( ton )

$\mathrm{Pa}_{2}=$ Lateral force pressure land active ( ton )

$\mathrm{Pp}=$ Lateral force pressure land passive (ton )

\section{CONCLUSIONS}

Manual calculation of the results and analysis of FINITE ELEMENT programs above it can be concluded that in the presence of an additional retaining her 400 spunpile $\mathrm{mm}$ using a distance $200 \mathrm{~cm}$ and a depth of $12 \mathrm{~m}$ along the circumference of a bozem placed on the ends of the base of the bozem wall, retaining wall construction is then quite able to hold style pillow case and Sliding with Style has a safety factor (security number) more than 1.5. So the sliding wall movement improvements do not happen again.

\section{REFERENCES}

[1] Bowles, J.E.,( 1977 ), Foundation Analysis and Design, McGraw - Hill kogakusha, Ltd., Tokyo, Japan.

[2] Bowles, J.E.,( 1984 ), Physical and Geotecnical Properties of Soil, McGraw - Hill Book Company, USA.

[3] Das, B.M.,( 1983 ), Advanced Soil Mechanics, McGraw - Hill, New York,

[4] R.B.J Brinkgreve, ( 2007 ), Plaxis b.v., Delft University Of Technology, Belanda.

[5] Terzaghi K, Peck R.B ( 1967 ), Soil Mechanics in Engineering Practice. John Wiley \& Sons, 1967.

$$
\begin{aligned}
\mathrm{Kp}= & \tan ^{2}(45+\varphi / 2) \\
= & \tan ^{2}(45+12 / 2) \\
= & 1,52 \\
\mathrm{Pp}= & 1 / 2 \times \gamma_{\text {sat }} \times \mathrm{H}^{2} \times \mathrm{Kp} \times 0,4 \mathrm{~m} \\
= & 0,5 \times 1,96 \mathrm{t} / \mathrm{m}^{3} \times 12^{2} \mathrm{~m} \times 1,52 \\
& \quad \mathrm{x} 0,4 \mathrm{~m} \\
= & 85,8 \text { ton }
\end{aligned}
$$

